elevated temperature and pressure of granitic rocks, Report LA-7224-T, Los Alamos Scientific Laboratory, Los Alamos, N. Mex., 1978.

Pratt, H. R., H. S. Swolfs, W. F. Brace, A. D. Black, and J. W. Handin, Elastic and transport properties of an in situ jointed granite, Int. J. Rock Mech. Min. Sci. and Geomech. Abstr., 14, 35, 1977.

Prickett, G. R., Properties of the Rocky Mountain arsenal disposal reservoir and their relation to Derby earthquakes, Quarterly of the Colo. School of Mines, 63(J), 73, 1968.

Rummel, F., Gesteinsphysikalische Daten des Falkenberger Granits, Annual Report BMFT ET-4150/ $C E C E-8(D)$, Institut für Geophysik, Ruhr-Universität Bochum, 1979.
Rummel, F., Physical properties of the rock in the granitic section of borehole GPK1, Soultz-sousforêts, Report $E E C E N-3 G-0092-D$, Institut für Geophysik, Ruhr-Universität Bochum, 1990.

Snow, D. T., Rock fracture spacings, openings, and porosities, J. Soil Mech. Foundations Div., 94, 73, 1968

van Pollen, H. and D. B. Hoover, Waste disposal and earthquakes at the Rocky Mountain arsenal, Derby, Colo., J. Petrol. Technol., 22, 983, 1970.

Voegele, M., R. McCain, M. Gronseth, and H. Pratt, In situ permeability measurements for an underground compressed air storage project, in Proc. 3rd Intemat. Well-Testing Symposium: Well Testing in Low Permeability Environments, Report $L B L-12076$, edited by T. W. Doe and W. J.
Schwarz, Lawrence Berkeley Laborartory, Berke ley, Calif., 1981

West, F. G., P. R. Kintzinger, and W. D. Purtymun Hydrologic testing, geothermal test hole no. 2, Report LA-6017-MS, Los Alamos Scientific Laboratory, Los Alamos, N. Mex., 1975.

Wilson, C. R., P. A. Witherspoon, J. C. S. Long, R M. Galbraith, A. O. DuBois, and M. J. McPherson, Large scale hydraulic conductivity measurements in fractured granite, Int. J. Rock Mech. Min. Sci. \& Geomech. Abstr., 20(6), 269, 1983.

Zoback, M. D., \& Hickman, S., In situ study of the physical mechanisms controlling induced seismicity at Monticello Reservoir, S. Carolina, $J$. Geophys. Res., 87(B8), 6959, 1982.

\title{
Magmatic Contributions to Hydrothermal Systems
}

\section{PAGES 233-234}

Although there is agreement that many hydrothermal systems in the upper crust derive their thermal energy from magmas, debate continues over the extent to which magmas contribute water, metals, and sulfur to hydrothermal systems. A multidisciplinary seminar was held November 10-16, 1991, in Ebino and Kagoshima, Japan, to establish current understanding about this topic and to explore the major unanswered questions and the most promising research directions. The thirty-eight participants were from Japan (eighteen), the U.S. (thirteen), Canada and New Zealand (two each), and England, the Philippines, and Russia (one each). Disciplines represented were volcanology, geochemistry (volcanic-gas, water, isotopes, experimental, and modeling), igneous petrology, geothermal geology, economic geology, fluid-inclusion study, geophysics, and physical modeling.

The seminar was organized around five major topics: the composition of fluids in equilibrium with magma, the processes of fluid separation from magma and the nature of hydrothermal systems enveloping magmas, the geometry and dynamics of fluid flow in magma/hydrothermal systems, the signatures and importance of magmatic fluids in active hydrothermal and volcanic systems, and the signatures and importance of magmatic fluids in extinct hydrothermal systems.

\section{What Do We Know?}

By definition, magmatic fluids are aqueous fluids in chemical, isotopic, and therma equilibrium with igneous melt, regardless of the ultimate origin of the components. At depths up to a few $\mathrm{km}, \mathrm{H}_{2} \mathrm{O}$ is usually the major constituent, although the fluids can contain significant $\mathrm{CO}_{2}, \mathrm{SO}_{2}, \mathrm{H}_{2} \mathrm{~S}, \mathrm{NaCl}, \mathrm{KCl}$, $\mathrm{FeCl}_{\mathrm{x}}, \mathrm{CaCl}_{2}, \mathrm{HCl}, \mathrm{HF}$, and metals. Experimental data suggest that the $\mathrm{NaCl} / \mathrm{HCl}$ ratio of magmatic fluids decreases with decreasing pressure, such as during ascent in a volcano.

The salinity of fluids separating from a magma is controlled by pressure, the degree of crystallization, and the initial water and $\mathrm{Cl}$ contents of the melt. Chemical modeling shows that there are three types of saline fluids, based on their conditions of formation: early, moderately saline fluids from high-pressure melts of low water content; late, extremely saline fluids from low-pressure melts, and-most commonly-extremely saline fluids and a separate gas phase produced by immiscibility at pressures less than a few hundred $\mathrm{MPa}$.

It is also known that the partitioning of metals between melt and aqueous fluid is more strongly affected by pressure than temperature, with low pressure favoring the concentration of metals in the aqueous phase. Furthermore, the greatest interaction between magmatic and meteoric fluids around an intrusion appears to occur in a narrow zone separating regions of hydrostatic pressure (with brittle failure) from regions of lithostatic pressure (with plastic failure) at $350-400^{\circ} \mathrm{C}$

High-temperature steam of $\delta^{18} \mathrm{O}=$ $+7 \pm 2 \%$ and $\delta \mathrm{D}=-25 \pm 10 \% 0$ from active island-arc fumaroles is most likely of direct magmatic origin. This characteristic $\delta \mathrm{D}$ range is distinct from the commonly accepted "magmatic water box" $(8 \mathrm{D}=-40$ to $-80 \%$ ).

Magmatic contributions to extinct systems are more difficult to recognize. $\delta^{18} \mathrm{O}$ and $8 \mathrm{D}$ of alunite and phyllosilicates in acidsulfate deposits converge on the composition of high-temperature fumarole steam. A magmatic source of $\mathrm{SO}_{2}$ and $\mathrm{H}_{2} \mathrm{~S}$ can be deduced from coexisting alunite and pyrite in some epithermal deposits. Magmatic fluids are indicated by $\delta^{18} \mathrm{O}$ and $\delta \mathrm{D}$ compositions and cogenetic highly saline fluid inclusions in early alteration minerals of porphyry-copper deposits. In some cases these fluids appear to have deposited $\mathrm{Cu}$, but phyllic alteration associated with $\mathrm{Cu}$ mineralization in several well-studied North American deposits indicates a significant contribution from meteoric waters.

Porphyry-copper deposits may pass upward into acid-sulfate deposits, but there appears to be little gradation between adu- laria-sericite deposits and either acid-sulfate or porphyry deposits. It is also clear that the pressure-temperature history of hydrothermal systems beneath volcanoes is greatly influenced by processes such as caldera subsidence, sector collapse, and hydrothermal eruptions that can cause rapid pressure decreases.

\section{Major Unanswered Questions}

The following questions were identified as needing further research:

- What are the solubilities of volatiles in magmas? The solubility and behavior of sulfur-bearing phases (vapors, crystals, and immiscible melts) in silicate melts need to be determined systematically. Much additional information on mixed volatile solubilities is needed for realistic modeling of melts.

- How do metals partition between melts and the magmatic fluids? A comprehensive experimental program is needed emphasizing the role of sulfur and its speciation. Promising studies of metals in natural melt inclusions need to be augmented.

- What are the thermodynamic properties of saline solutions over a wide spectrum of temperatures, pressures, and $\mathrm{CO}_{2}$ concentrations? Data are restricted primarily to the $\mathrm{NaCl}-\mathrm{H}_{2} \mathrm{O}$ system and are incomplete, especially at high temperatures and low pressures. To interpret fluid-inclusion observations, PVTX data are needed at $200-900^{\circ} \mathrm{C}$, 10-200 MPa, and a range of fluid compositions (including effects of $\mathrm{KCl}, \mathrm{CaCl}_{2}, \mathrm{FeCl}_{\mathrm{x}}$, $\mathrm{NaCl}, \mathrm{CO}_{2}, \mathrm{H}_{2} \mathrm{~S}, \mathrm{SO}_{2}, \mathrm{CH}_{4}$, and $\mathrm{N}_{2}$ ).

- What are the compositions of magmatic fluids in crustal environments? Emphasis should be placed on micro-sampling methods for stable-isotope and gas compositions in individual fluid inclusions.

- What is the nature and origin of permeability in the marginal zones of magmas and immediately adjacent to magmas? Rheological properties that govern flow and fracture of magma and rocks at $200-900^{\circ} \mathrm{C}$ and 50 $300 \mathrm{MPa}$ need to be determined. Expanded field studies are needed to determine the nature and origin of porosity and permeability in marginal zones.

- What is the physical and chemical transition from the high-temperature near-magmatic environment to the lower-temperature hydrothermal systems? Relatively shallow drilling in a confined volcano-hydrothermal system such as White Island in New Zealand 
Ebino Plateau area of Kirishima andesite volcano, southern Kyushu, Japan, site of the Japan-U.S. Seminar on Magmatic Contributions to Hydrothermal Systems. The Iwoyama fumaroles (middle) discharge $175^{\circ} \mathrm{C}$ vapors with a small magmatic component $(\mathrm{HCl}$ and other gases) diluted by a meteoric hydrothermal system (J. W. Hedenquist and M. Aoki, "Meteoric interaction with magmatic discharges in Japan and the significance for mineralization," Geology, 19, 104l,
1991). Shinmoedake crater and fumarole, further to the southeast, were the site of a 1959 phreatic enuption. Seismic tremor beneath this crater began during the seminar, followed by increased fumarolic activity, and culminated 2 weeks later in mild ash eruption for several days. Demagnetization is now continuing. (Photo by Shu kosha Printing Co., Ltd.) [Original color image appears in the back of this volume.] shows particular promise for exploring this question.

- What similarities or differences are there in the composition and volatile evolution of ore-forming and barren magmas? Comprehensive comparative studies of the magmatic and hydrothermal evolution of orebearing and barren porphyry intrusions are needed, emphasizing fluid and glass inclusions and paragenesis of primary and hydrothermal phases.

- What are the mechanics, dynamics, and rates of formation of porphyry intrusions? Geologically constrained numerical modeling is required, involving the possibly non-linear interactions of magma composition and properties, pressure, stress, strain release, and hydraulic fracturing.

- Does the focusing of magmatic fluids from batholiths influence the size and style of ore and geothermal systems at higher levels? Regional geological and geophysical studies are needed of the igneous and teclonic environments of large porphyry deposits.

- What do the edges of hydrothermal systems look like and how do they merge with adjacent systems of different types? Most studies of hydrothermal systems, particularly those of ore deposits, focus on the central, strongly affected parts of the systems, neglecting the edges that may provide important genetic constraints.

- What is the duration of the mineralizing process? With the advent of precise isotopic age-measurements on individual fluid inclusions, it is becoming possible to distinguish events that differ little in age, thus addressing the question of the active life of hydrothermal systems.

- What are the geologic factors that produce "telescoping" of ore deposits? Integrated studies should address the effects that abrupt events in shallow volcanic and geothermal environments have on deep pressures, with resultant changes in the exsolution of volatiles from magma and the distribution of metals between the melt and the aqueous phase.

- Do the high-temperature and high-pressure environments that exist at depth in some active geothermal systems represent a transition to a potentially mineralized por- phyry environment? These environments have been encountered at $\sim 3 \mathrm{~km}$ in four geothermal areas throughout the world, but no quantitative information is available other than approximate temperatures $\left(>400^{\circ} \mathrm{C}\right)$ and pressures ( $>24 \mathrm{MPa}$ in excess of hydrostatic). A program is needed to determine the temperatures, fluid compositions, and the nature of the rock in the pressure-transition zone.

- How does the interaction of magma with hydrothermal systems influence or trigger volcanic eruptions? Studies are needed to evaluate and amplify the suggestion that the anhydrite and high $\mathrm{SO}_{2}$ in the products of Nevado del Ruiz and Pinatubo volcanoes are related to the vaporization of a hydrothermal system by magmatic intrusions.

\section{Conclusions}

Investigations to date have produced a general framework for the interaction of magma and hydrothermal systems. Some important advances can be made simply by broadening the communication and cooperation among disciplines and viewing this 
complex topic from many perspectives. Fundamentally, however, understanding mag matic contributions to hydrothermal systems will require expanded experimental investigations, numerical modeling, field studies, and drilling.

Principal sponsors of the meeting were the Japan Society for the Promotion of Science and the U.S. National Science Foundation, under the Japan-U.S. Cooperative Science Program. Associate sponsors included the Geological Survey of Japan, Kagoshima and Miyazaki Prefectures, the Kagoshima University Research Center for the South $\mathrm{Pa}$ cific, the Metal Mining Agency of Japan, the Tsukuba Expo 85 Fund, and the U.S. Geolog ical Survey.

Extended abstracts by all attendees and an expanded version of this report, which is based on summaries of group discussions at the seminar, will be published in mid-1992 as Report 279 of the Geological Survey of Japan, available outside North America for the cost of postage from Jeffrey Hedenquist, G.S.J., Higashi 1-1-3, Tsukuba 305, Japan, Fax 81-298-54-3533. Within North America, obtain copies from Patrick Muffler, USGS, MS 910, Menlo Park, CA 94205; fax 415-329-5203; e-mail pmuffler@mojave.wr.usgs.gov._L.J. Patrick Muffler, U.S. Geological Survey; Jeffrey W. Hedenquist, Geological Survey of Japan; Stephen E. Kesler, Department of Geological Sciences, University of Michigan, Ann Arbor; and Eiji Izawa, Faculty of Engineering, $\mathrm{Ky}$ ushu University, Hakozaki 6-10-1, Higashiku, Fukuoka, 812, Japan

\section{NASA's Small Planetary Mission Plan Released}

\section{PAGE 234}

A ten-page report just submitted to Congress outlines a new strategy for NASA planetary programs emphasizing small missions. If implemented, this plan would represent a shift away from large "flagship" missions that have characterized many programs of NASA's Solar System Exploration Division.

There are a number of reasons for this shift in strategy. The current NASA appropriations bill requires "a plan to stimulate and develop small planetary or other space sci ence projects, emphasizing those which could be accomplished by the academic or research communities." Budgetary realities make it more difficult to fly large missions. There is also concern about a "significant gap" in data from planetary missions between 1998 and 2004.

Under this plan, small planetary projects would have focused scientific objectives and utilize a limited number of mature instruments, with little or no development of new technology. University/industry partnerships would be responsible for mission implementation over a period of less than 3 years, working within firm cost ceilings. The missions would be riskier, although less would be at stake.

NASA has experience with projects of this size, having launched sixty-six Explorer spacecraft such as the Cosmic Background Explorer and the Infrared Astronomical Satellite. A number of other Explorer missions are under development. The report describes two new initiatives. The first is "Discovery," a series of inner solar system programs. An example of a Discovery program is the Mars Environmental Survey Pathfinder (MESUR). This mission would establish sixteen small stations on Mars to study its meteorology, internal seismic activity, and local surface properties. Another Discovery program would be a Near-Earth Asteroid Rendezvous (NEAR) mission. The report envisions a total mission cost of up to $\$ 150$ million.

On May 8, NASA awarded initial mission studies of MESUR to the Jet Propulsion Laboratory and NEAR to the Applied Physics Laboratory of Johns Hopkins University. The two missions are scheduled for launch in 1996 and 1998 , respectively.

The second category of initiatives is entitled "Toward Other Planetary Systems," focusing on whether or not our solar system is unique. Important in this effort, which would largely consist of ground-based observatories, is the construction of a second 10meter telescope at the Keck Observatory in Hawaii. The cost of this program through 1999 would be less than $\$ 100$ million.

NASA has been working on the Small Planetary Projects Plan for more than a year, and is requesting $\$ 10$ million for fiscal year 1993 for this activity. The report states that "NASA will continue to seek new candidate small projects. Emphasis will be on developing additional Discovery missions and on the study of scientifically focused, small missions to the outer planets. Outer planet concepts will have to have strictly limited scientific objectives to meet small mission cost criteria. These studies will involve academia and independent research institutions so that their interest and capabilities can continue to be appraised."--Richard M. Jones, American Institute of Physics

\section{Earth Summit Science, Policy Discussed}

\section{PAGES 234-235}

The United Nations Conference on Environment and Development, the "Earth Summit," convenes in Rio de Janeiro on June 3. President Bush has pledged to attend part of the 2-week conference. The highlight of the summit will be the signing of an international framework convention to reduce emis sions of greenhouse gases. The final elements of the agreement were negotiated in New York last week by representative of 143 countries. In anticipation of the Rio conference, the Senate Committee on Energy and Natural Resources held two standing-roomonly hearings, reviewing the scientific basis for global warming due to greenhouse gases and discussing the details of the proposed convention.

The committee's chairman is J. Bennett Johnston (D-La.), author of S2166, the National Energy Security Act of 1992, which was recently passed by the Senate. At the first hearing on May 6, Johnston probed disagreements among experts in the field of global climate change. While opinions varied among the four witnesses over the effect of human actions, all agreed with the assess ment of the Intergovernmental Panel on Climate Change that global temperatures have increased $0.3^{\circ}-0.6^{\circ} \mathrm{C}$ over the past century. Robert Watson, Chief of Atmospheric Chemistry at NASA, added that concentrations of greenhouse gases are increasing due to human activity, and current circulation models predict that this will result in more warming.

The scientists concurred that significant uncertainties made policy decisions difficult. Steven Schneider of the National Center for Atmospheric Research got no argument when he advocated a "prudent response." He recommended first taking actions that are beneficial in any case, such as improving energy efficiency, and taking stronger action if further data warrants it. This "no-regrets" strategy is favored by the Bush Administration. Michael MacCracken of Lawrence Livermore National Laboratory added that "there's no such thing as a free lunch; the public has to realize" they can't have "a certain lifestyle with no risk."

The policy of the administration has been to resist setting rigid emission reduction goals. None of the scientists felt that such arbitrary goals would be particularly useful. Pete Domenici (R-N.Mex.) recapitulated their advice: "I don't hear any of you saying we should fix targets and goals."

On May 12, Johnston's committee heard from various members of the administration involved in negotiating the Earth Summit convention. The convention, as advocated by the Bush Administration, focuses on all greenhouse gases, not just carbon dioxide. It does not, however, dictate specific reduction goals. Instead, according to Robert Reinstein, a Deputy Assistant Secretary at the Department of State, the agreement calls on industrialized countries to "take the lead in limiting greenhouse gases" and providing information on the actions taken and their results. It also provides for partnerships between industrialized and developing nations for technology transfer and cooperation in research and monitoring.

Department of Energy Acting Deputy Secretary Linda Stuntz called the convention "an action-oriented package" that rejects arbitrary, rigid time tables and "allows each nation to pursue [reductions] without harm to their economy." She stated that "no nation has set forth a plan to reduce emissions in the level of detail the U.S. has done" in its National Energy Strategy. Stuntz testified that the NES was expected to hold greenhouse gas emissions "near" 1990 levels through 2000, but not stabilize them exactly. Richard Morganstern, Assistant Administrator for Policy Planning and Evaluation at the Environmental Protection Agency, added that a $7-11 \%$ reduction was expected from otherwise projected emission levels. All the administration witnesses supported Johnston's energy bill as an important step in the right direction, although Stuntz noted that the administration also plans to take additional actions. 
